\title{
Del trazado a la construcción: Versatilidad de las bóvedas de crucería
}

\author{
From conceptual layout to construction: \\ Versatility of cross ribbed vaults
}

R. Martín ${ }^{(*)}$, R. Maira ${ }^{(*)}$

RESUMEN

La bóveda de crucería supuso un notable avance en el desarrollo de la construcción medieval, ya que permitió resolver el cerramiento de muy variados espacios mediante la articulación de elementos como los nervios y los plementos. Este sistema se caracterizó por su elevada flexibilidad y versatilidad, lo cual permitió optimizar recursos y esfuerzos en unos diseños cada vez más complejos. En el presente artículo se describen una serie de análisis concretos de bóvedas de crucería, recogiendo ejemplos de diversas épocas y autores, para mostrar los distintos recursos empleados en el proceso constructivo. En todos ellos, sea cual sea su forma final, subyace una atención fundamental por la simplificación y sistematización de la ejecución, que lleva a sus autores a emplear diferentes métodos constructivos y a alterar la integridad geométrica del diseño. Ello demuestra el profundo saber hacer constructivo que poseían, logrando a un mismo tiempo soluciones optimizadas sin perder la brillantez formal de sus creaciones.

970-4

Palabras clave: Bóveda de crucería; construcción; geometría; estereotomía; arco; dovela; clave.

\section{SUMMARY}

The cross ribbed vault was a very important advance for construction technology, because it allowed almost any space to be covered by joining together a group of arches that supported a light surface. This system was characterized by its high flexibility and versatility, which allowed the construction process to be optimized while the designs became more complex. This article presents several detailed analyses of some cross ribbed vaults that belong to different chronological periods and were designed by various authors, in order to show the resources that were used during their construction. Despite their specific form, a search for the simplification and systematization of the constructive process underlies them all, which sometimes caused the modification of the design's geometrical pureness. This shows the deep constructive knowledge of their authors, who developed optimized solutions without losing the formal elegance of the vaults.

Keywords: Cross ribbed vault; construction; geometry; stereotomy; arch; voussoir; keystone. 


\section{INTRODUCCIÓN}

Uno de los principales hitos en el desarrollo de la tecnología constructiva histórica estuvo marcado por el empleo del sistema de crucería para cubrir los espacios. Frente a las bóvedas de arista y de cañón románicas, basadas en fábricas continuas y homogéneas que repartían las cargas indiscriminadamente por todo su perímetro de apoyo, la crucería gótica estuvo caracterizada por la articulación de dos elementos: nervios y plementos. De este modo, se consiguió obtener un sistema basado en líneas maestras (nervios) sobre las que apoyaba un cierre ligero (plementería), lo cual supuso una especialización constructiva y estructural que aportó notables ventajas (1). El desarrollo progresivo del sistema de crucería gótica evolucionó desde las bóvedas sexpartitas y cuatripartitas de sencillos trazados, hasta las construcciones tardogóticas, caracterizadas por una notable complejidad de sus redes nervadas (2). Así, gracias a la versatilidad del sistema constructivo, pudieron construirse las más variadas formas, manteniendo en todo momento unos sencillos principios geométricos.

La geometría fue la herramienta fundamental que permitió desarrollar los trazados de las bóvedas de crucería, desde la planta a las curvaturas de los nervios. Es muy extensa la bibliografía que ha tratado el sustrato geométrico de las construcciones góticas, y ponen de relieve su notable importancia para el diseño de las mismas. Sin embargo, no debe olvidarse que la concepción geométrica y el diseño eran herramientas al servicio de la construcción de las bóvedas, derivando en lo que algunos autores han venido Ilamando la geometría constructiva (3).

En el presente artículo se muestran una serie de casos concretos, derivados del estudio directo de varias bóvedas de crucería de diversos periodos, en los que se han detectado algunos recursos y soluciones prácticas que, si bien alteran la integridad de una concepción geométrica ideal, consiguen notables ventajas constructivas. De este modo se pone de manifiesto la elevada versatilidad del sistema gótico, gracias a la cual pudieron realizarse estas modificaciones y ajustes, que permitieron a los maestros canteros alcanzar una optimización y simplificación del proceso constructivo.

\section{CONSTRUCCIONES SOBRE ESTRUCTURAS PREEXISTENTES}

Los edificios históricos son el fruto de una serie de acciones constructivas y destructivas, en los que las transformaciones se

\section{INTRODUCTION}

One of the principle milestones in the development of historical construction technology was marked by the use of cross ribbed vaults to cover spaces. In contrast to Romanesque groin and barrel vaults, based on continuous and homogeneous stonework that spread loads indiscriminately on the entire supporting perimeter, the Gothic cross ribbed vault featured the articulation of two elements: ribs and severies.

In this way, a system based on guidelines (ribs) supporting light compartments (severies) could be achieved, which gave rise to a specialized construction and structural technique that brought with it important advantages (1). The gradual development of the Gothic rib system evolved from sexpartite and quadripartite vaults of simple conceptual layout, towards late Gothic constructions with highly complex ribbed webs (2). Thus, thanks to the versatility of the constructive system, a great variety of forms could be built, maintaining at all times simple geometric principles.

Geometry was the fundamental tool that enabled the design of cross ribbed vaults to be developed, from plan to curvature. There is an extensive bibliography which highlights the great importance of the geometric substrate for the design of Gothic constructions. However, it should not be forgotten that both the geometric conception and the design were tools at the service of the construction of vaults, resulting in what some authors call constructive geometry (3).

This article presents a series of specific cases taken from the direct study of several cross ribbed vaults from different periods. Practical strategies and solutions have been detected which, while they alter the integrity of an ideal geometric conception, achieve important constructive advantages, highlighting the great versatility of the Gothic system. It is thanks to this flexibility that these modifications and adjustments could be made, enabling master masons to optimize and simplify the construction process.

\section{CONSTRUCTION ON PRE-EXISTING STRUCTURES}

Historical buildings are the result of a series of constructive and destructive actions, in which transformations follow one after the other over time. Therefore, master masons on many occasions had to adapt to preexisting conditions, which were not always 
sucedían a lo largo de su historia. Por ello los maestros canteros debieron en numerosas ocasiones adaptarse a condiciones preexistentes, no siempre favorables. Así, el sistema gótico, basado en la articulación de nervaduras y plementos ofrecía una gran versatilidad frente a los abovedamientos ejecutados íntegramente con sillería. De este modo, la construcción de bóvedas de crucería sobre estructuras preexistentes exigía la adaptación del trazado de la nervadura a los soportes ya construidos.

\subsection{Bóvedas de nave}

Las bóvedas sexpartitas de la catedral de Sigüenza son un ejemplo de bóvedas del primer gótico construidas sobre fábricas románicas preexistentes. Probablemente sus obras comenzaron por la cabecera antes de 1156, benedictina, con cinco ábsides escalonados. Antes de ejecutar las cubiertas, llegan nuevos maestros y hay un cambio de proyecto. Lambert considera este segundo proyecto perteneciente a la escuela cisterciense hispano-lanquedociana (4). Posteriormente hubo un tercer cambio. Se eleva la altura de los muros hasta el arranque de las bóvedas actuales, construyendo un segundo cuerpo con decoraciones góticas. Este nuevo proyecto comprende además la elevación de las bóvedas que cubren el presbiterio y los brazos del crucero. La mayoría de investigadores data este tercer proyecto entre 1221 y 1226 (5), mientras que otros lo sitúan a finales del siglo XIII (entre 1271-1299) (6).

Al analizar las bóvedas del crucero sur y norte, vemos que comparten dos características que en un primer análisis parecen responder a las deformaciones del edificio o incluso a posibles errores de replanteo. En la bóveda sexpartita del crucero sur, su arco de través, es decir, el que divide a la bóveda en sus dos mitades simétricas, tiene su arranque ligeramente desplazado hacia el sur. Además su formero sureste es notablemente más pequeño que los demás.

En la bóveda norte, ocurre exactamente lo mismo, estando el arranque de su arco de través desplazado hacia el norte y siendo su formero norte más pequeño. Esta particularidad parece responder a la adaptación de las bóvedas góticas a las antiguas fábricas románicas que formaban los cinco ábsides escalonados ya desaparecidos (Figura 1).

La diferencia de tamaño entre los dos ábsides laterales de cada lado, determinó el tamaño de los formeros y la posición del arranque del arco de través, que no se encuentra en el centro geométrico del lado. Al estar su clave en el centro geométrico de la favourable. The Gothic system, based on the articulation of ribs and severies offered great versatility compared to vaults built with ashlars alone. Thus to build cross ribbed vaults on existing structures the conceptual layout of the ribs had to be adapted to the supports already built.

\subsection{Nave vaults}

The sexpartite vaults in Sigüenza Cathedral are an example of Early Gothic vaults built on pre-existing Romanesque masonry. Work probably began before 1156 on the Benedictine chevet, which had five stepped apses. Before the roofs were built, new masons arrived and the design was changed. Lambert believes that this second design belongs to the Cistercian SpanishLanguedoc School (4). Subsequently there was a third change. The walls were raised to the level of the springers of the vaults that are there today, building a second body with Gothic decoration. This new design also involved the elevation of the vaults that cover the presbytery and the arms of the transept. Most researchers date this third design between 1221 and 1226 (5), while others date it at the end of the 13th century (between 1271 and 1299) (6).

When analysing vaults in the south-north transept, we see that they share two characteristics which at first appear to be the result of the building's deformations or even of possible errors of site layout. In the sexpartite vault in the south transept, the base of the transverse arch, that is the one that divides the vault into two symmetrical halves, is positioned slightly off centre towards the south. Also its southeast wall rib is noticeably smaller than the rest.

In the north vault, exactly the same thing happens. The base of the transverse arch is slightly to the north and its north wall rib is smaller. The explanation for this peculiar characteristic seems to be the adaptation of Gothic vaults to the old Romanesque masonry of the five stepped-apses which have now disappeared (Figure 1).

The difference in size between the two side-apses, determined the size of the wall ribs and the position of the base of the transverse arch, which is not in the geometric centre of the side. Since the keystone is in the geometric centre on plan, the rib turns slightly from the start to reach it. This curvature can be spotted immediately, but the difference in size between the wall ribs can only be detected by topographic measuring. Although the north transept vault was bombed during the Spanish Civil War, and later reconstructed 
1. Arcos formeros de diferente tamaño en las bóvedas sexpartitas del crucero de la catedral de Sigüenza, adaptándose a la cabecera románica de cinco ábsides desaparecida. Montaje realizado con la nube de puntos elaborada de las bóvedas sexpartitas de la catedral de Sigüenza (toma de datos con estación total Leica TCR1105), y con la planta realizada por $P$. Dumont (según M. Pérez Villamil) de la posible cabecera románica primitiva desaparecida (4).

1. Different size of wall ribs of the sexpartite vaults of the transept of Sigüenza Cathedral which were adapted to the old Romanesque masonry of the five stepped-apses which have now disappeared. The plan of the possible Romanesque chevet was drawn by P. Dumont (4) (according to M. Pérez Villamil). Point cloud elaborated with Total Leica TCR1105 station.

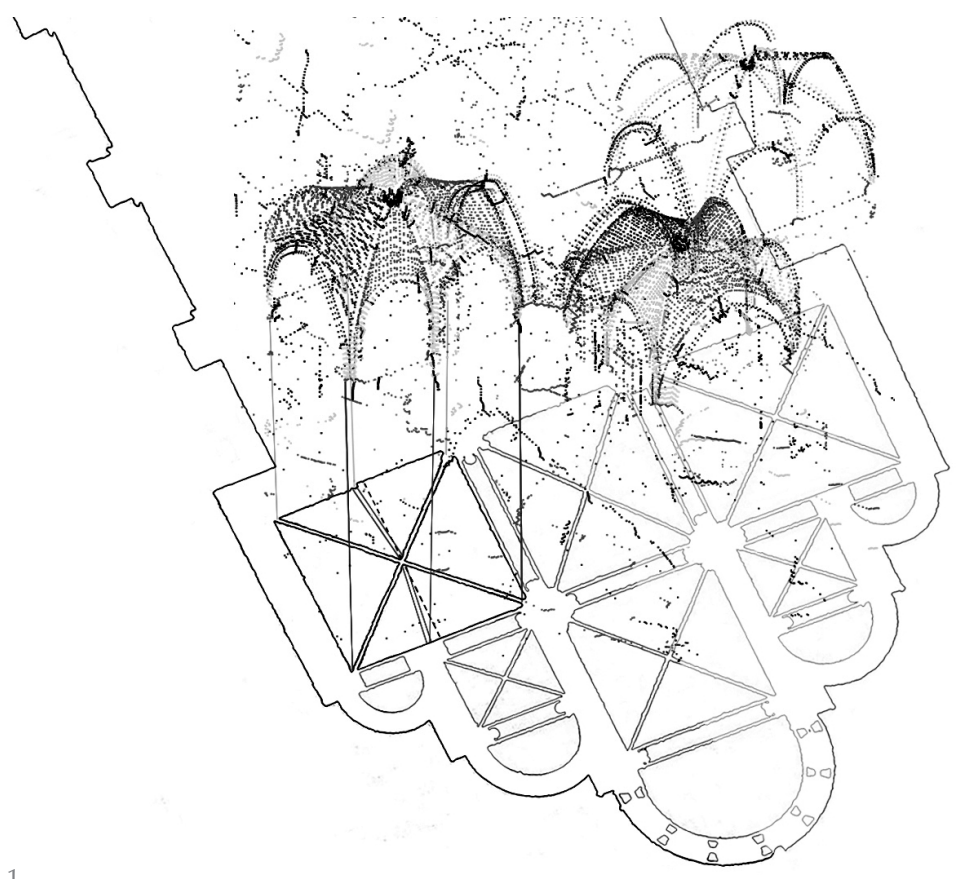

planta, el nervio gira ligeramente desde el arranque para alcanzarla. Su desviación se ve a simple vista, en cambio la diferencia de tamaño en los formeros solo se detecta con la medición topográfica. Aunque la bóveda del crucero norte fue bombardeada durante la guerra civil y posteriormente reconstruida por Antonio Labrada en los años 40, presenta estas mismas características, ya que las ménsulas de apoyo y los arranques de los arcos de sus bóvedas se conservaron (7), por lo que no se modificaron estas características iniciales.

\subsection{Bóvedas rebajadas}

El segundo ejemplo corresponde a la bóveda rebajada del sotocoro del monasterio de San Benito el Real, en Valladolid. La última etapa constructiva del edificio corresponde con la terminación del coro alto, que según la documentación existente, se llevó a cabo bajo el gobierno de Fray Alonso de Toro, entre 1524 y 1542 (8) -aunque desconocemos su autoría-, y fue ejecutado sobre los pilares ya existentes del tramo occidental de la nave. La planta presenta un trazado complejo, compuesto íntegramente de nervios rectos en planta (Figura 2).

Los pilares del coro están construidos a modo de forros de fábrica de los soportes existentes de la nave. Los ubicados en el frente hacia la nave se componen de un conjunto de columnas adosadas a un núcleo central, con un basamento común y rematadas por capiteles que sirven de arranque a cada nervio. Por su parte, los soportes situados en el muro testero se insertan en la fábrica, y también tienen columnas adosadas a un núcleo central que by Antonio Labrada in the 1940s, these same characteristics can still be seen, since the corbels and the springers of the vaults have been preserved (7) and therefore these original features have not been changed.

\subsection{Surbased vaults}

The second example is the surbased vault in the underchoir in the Monastery of San Benito el Real in Valladolid. The upper choir was the last part of the building to be finished, and according to existing documentation, was carried out under the government of Fray Alonso de Toro, between 1524 and 1542 (8) -although the author is unknownand was built on the existing columns of the western section of the nave. The plan shows a complex conceptual layout, in which all the ribs are straight (Figure 2).

The columns in the choir are built as a kind of masonry cladding on the existing supports in the nave. The ones facing the nave are made up of a group of columns around a central nucleus with a common base and topped with capitals that serve as the base for each rib.

The supports located on the front wall are inserted in the masonry, and also have columns around a central nucleus that supports the ribs. In this way, although they have a similar typology, their perimeter on plan is very different, and the layout of the vault would have had to be adapted to the existing structure. In spite of this asymmetry on the supports, the keystone of the vault has been maintained at the central point of the perimeter of the rectangle of the vault, which means that it is off-centre with regard 


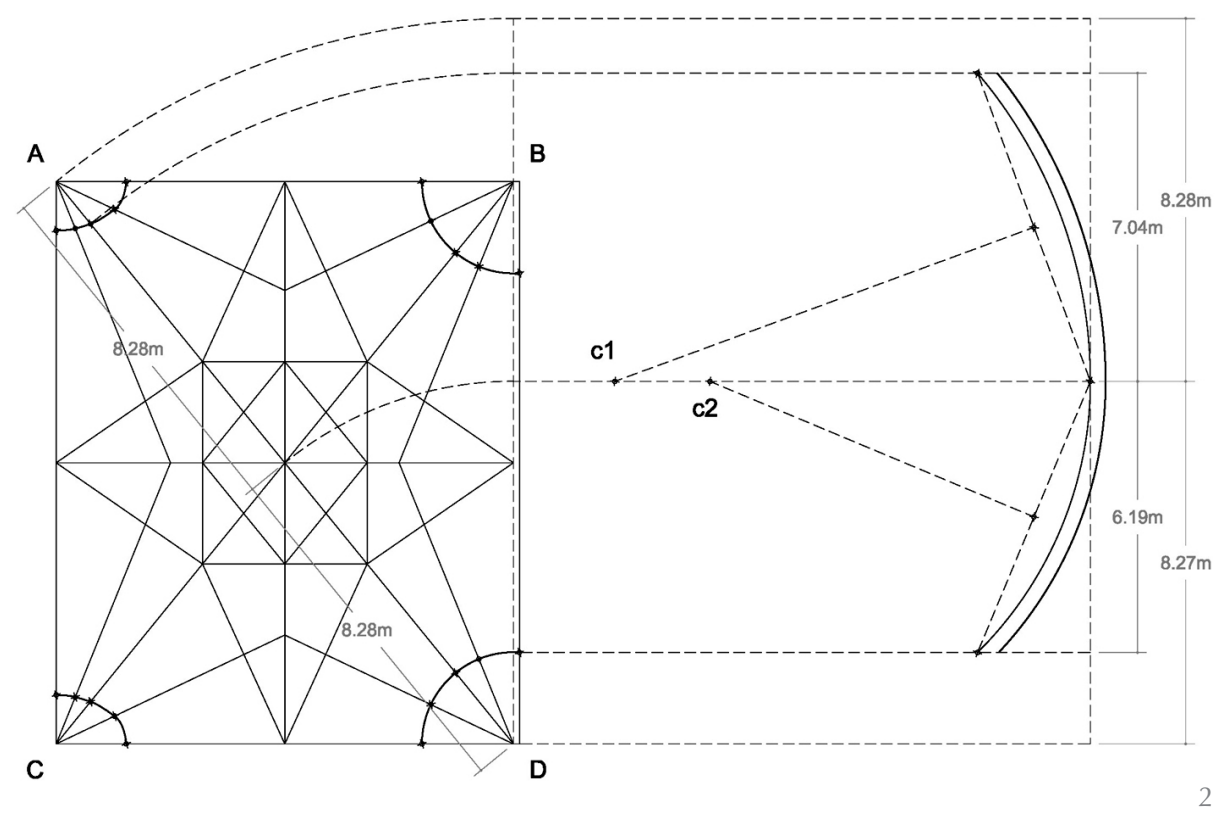

2

recoge el apoyo de los nervios. De este modo, aunque tipológicamente son similares, su perímetro en planta es muy distinto, por lo que habría sido preciso un ajuste del trazado de la bóveda a la estructura existente. A pesar de esta asimetría en los soportes, la clave de la bóveda se ha mantenido en el punto central del rectángulo perimetral de la bóveda, lo cual implica que queda descentrada respecto de la luz de los nervios ojivos y perpiaños.

Al analizar la forma de los nervios ojivos mediante un levantamiento topográfico, se observa una característica muy singular, ya que tienen un trazado fuertemente asimétrico, que no responde a las deformaciones detectadas en la fábrica. Como se ha mencionado, los puntos de arranque en planta no están situados de modo simétrico respecto de la clave central, o dicho de otro modo, la clave central no está ubicada en el punto medio de la luz de los arcos. Por ello, el trazado de los nervios ojivos se vio condicionado por esta situación de partida, que se habría resuelto mediante el empleo de dos curvaturas distintas para un mismo arco; a partir de la clave, se trazarían sendas ramas -con la condición de tangencia horizontal en su salida- hasta cada uno de los puntos de arranque, los cuales, al estar ubicados a distancias diferentes respecto de la clave, obligarían a emplear curvaturas distintas a cada lado. De este modo, las condiciones iniciales asimétricas y dificultosas se habrían resuelto gracias a la versatilidad del sistema gótico de nervaduras, que permite todo tipo de ajustes y adaptaciones, consiguiéndose además una sistematización y repetición de las curvaturas de los nervios principales en los terceletes, sin que en ningún momento quede afectada la percepción equilibrada y aparentemente simétrica del resultado final. to the span of the diagonal and transverse arch.

By carrying out a topographic survey to analyse the form of the diagonal ribs, a very distinctive characteristic can be observed, since they have an extremely asymmetric layout, that does not correspond to the deformations detected in the stonework. As already mentioned, the springers are not symmetrical to the central keystone on plan, or in other words, the central keystone is not in the middle of the span of the arches. For this reason, the design of the diagonal ribs was conditioned by this starting point, a problem which was resolved through the use of two different curvatures for one same rib: different branches were drawn from the keystone to each of the springers. These branches began by being horizontal tangents but as the springers were at different distances from the keystone, the branches required the use of different curvatures on each side. In this way, the initial asymmetric and difficult conditions would have been overcome thanks to the versatility of the Gothic system of ribs, which allows for all types of adjustments and adaptations, and at the same time achieves a systematization and repetition of the curvatures of the main ribs in the tiercerons, without affecting the balanced and apparently symmetric perception of the final result at any time.
2. Planta y elevación del nervio ojivo de la bóveda del sotocoro del convento de San Benito (Valladolid).

2. Plan and elevation of the diagonal rib of the vault in the underchoir of the convent of San Benito (Valladolid). 
3. Jarjas del refectorio del monasterio de Santa María de Huerta (arriba), catedral de Ávila (centro) y catedral de Sigüenza (abajo)

3. Tas-de-charges in the Santa María de Huerta monastery refectory (top), Ávila Cathedral, (centre) and Sigüenza Cathedral (bottom)
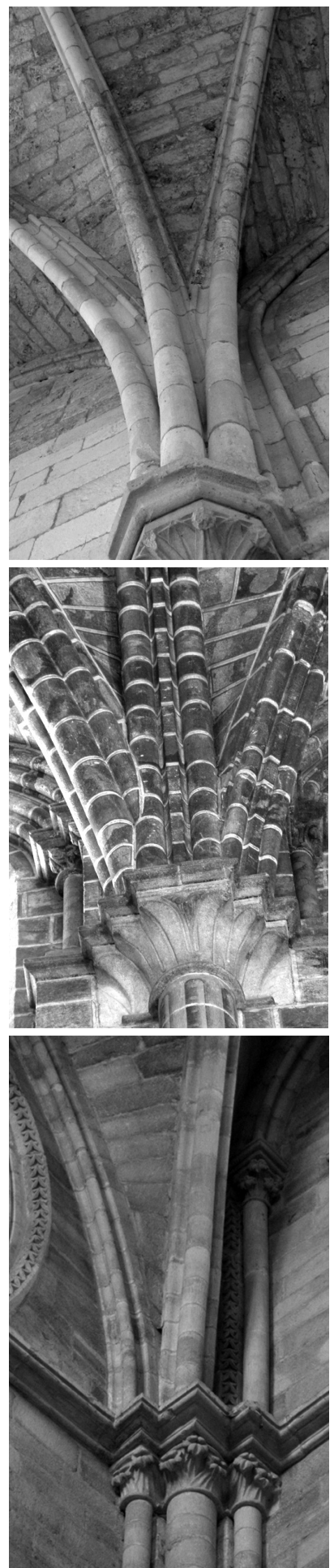

\section{CONSTRUCCIÓN DE LAS JARJAS}

\subsection{Intersección de los nervios}

El enjarje lo constituyen las piezas que engloban todo el haz de nervios de la bóveda, y que tienen sus lechos horizontales. Según los diversos autores que han estudiado el tema (9), su trazado comenzaría con la determinación de los ejes de los nervios, que se cortarían en un único punto, correspondiente al centro de la jarja. A partir de dicho punto, se irían colocando las plantillas de testa de los nervios en sus diversas alturas, en concordancia con las elevaciones de cada arco previamente trazadas. Podemos observar jarjas de este tipo en las bóvedas del refectorio gótico de Santa María de Huerta (1223-1225) (Figura 3 arriba).

Aunque la teoría de construcción de las jarjas es ya una cuestión muy estudiada, en la práctica podemos encontrar interesantes ejemplos que la contradicen. En las bóvedas de la cabecera de la catedral de Ávila (1172, construidas por el maestro Fruchel), podemos observar como el arquitecto, quizá por desconocimiento, no ejecuta jarjas en los arranques de los nervios, resultando una solución algo tosca. El arco perpiaño comienza sobre la cornisa de apoyo, y los arcos ojivos se empotran contra él, algo más arriba, cortándose de forma aparentemente improvisada en las zonas de intersección y uniéndose al arco perpiaño con mortero de cal (Figura 3 centro). No hay jarja propiamente dicha, ya que las dovelas están sueltas.

En cambio, en el crucero de la catedral de Sigüenza (siglo XIII), la solución adoptada es distinta a la anterior aunque tampoco se ajusta a la teoría de Viollet-le-Duc. En este caso tampoco hay jarjas ya que los arcos son independientes entre sí (Figura 3 abajo). Simplemente van colocados unos al lado de otros, por lo que el espacio que ocupa en planta su arranque es mucho mayor.

\subsection{Desplazamiento de los nervios}

La historiografía especializada ha asumido de un modo generalizado el hecho de que el diseño de las jarjas se basa en el trazado de sus ejes en planta, de tal modo que confluyan en un único punto, generalmente las esquinas del perímetro de la bóveda. Esta hipótesis presenta una sencilla y ventajosa aplicación en los abovedamientos cuatripartitos o sexpartitos. Sin embargo, en las bóvedas tardogóticas, la multiplicación de nervios y la aparición de los terceletes causaron algunos problemas, ya que el mayor número de nervios acometiendo a un mismo punto complicaba las intersecciones.

\section{CONSTRUCTION OF THE TAS-DE-CHARGES}

\subsection{Intersection of the ribs}

All the parts that make up the ribs in the vault are in the tas-de-charge, in horizontal courses. Authors that have studied the subject (9), claim that the conceptual layout would be achieved by first determining the axes of the ribs, which would cross at one single point, corresponding to the centre of the tas-de-charge. From that point, the templates of the ribs would be placed at different heights, in accordance with the elevations of each previously drawn arch. Tas-de-charges of this type can be seen in the gothic refectory vaults at Santa María de Huerta (1223-1225) (Figure 3 top).

Although the theory behind the construction of the tas-de-charges has already been widely studied, in practice, we can find interesting examples to contradict it. In the vaults in the chevet of Ávila Cathedral (1172, built by Master Fruchel), we can observe how the architect, perhaps through ignorance, does not build the tas-de-charges at the springers of the ribs, which produces a rather crude solution. The transverse arch, springs from the supporting cornice and the diagonal ribs are embedded in it a little further up. This intersection seems to have been improvised since the diagonal ribs seem to have been cut roughly where they should cross and joined to the transverse arch with lime mortar (Figure 3 centre). There is no real tas-de-charge since the voussoirs are loose.

By contrast, in the transept in Sigüenza Cathedral $\left(13^{\text {th }}\right.$ century) the solution adopted differs from the above although it still does not adjust to the theory presented by Viollet-le-Duc. Here there are no tas-decharges either since the arches are separate from each other (Figure 3 bottom). They are simply placed one next to the other, and therefore occupy more horizontal space.

\subsection{Displacement of the ribs}

Specialised historiography has generally accepted the fact that the design of tas-decharges is based on the conceptual layout of their axes on plan, so that they converge at one point, generally the corners of the perimeter of the vault. This theory presents a simple and advantageous application in quadripartite or sexpartite vaults. However, in late Gothic vaults, the multiplication of the ribs and the appearance of tiercerons began to cause problems, since the greater number of ribs converging at one same point complicated the intersections. 
A raíz del estudio directo de algunas bóvedas rebajadas tardogóticas y modernas, se ha comprobado que en numerosas ocasiones no se cumple el criterio del cruce de los ejes de los nervios en un único punto. De hecho, es bastante usual que los nervios de mayor tamaño -generalmente los perpiaños- se separen del resto, de modo que su eje quede desplazado, evitando así intersecciones inadecuadas en las jarjas. Se exponen dos casos opuestos en la Figura 4. En la bóveda del sotocoro del convento de San Telmo (San Sebastián) -construido entre 1544 y 1562 con trazas de Fray Martín de Santiago-, el nervio perpiaño queda desplazado respecto de los nervios interiores, facilitando así la ejecución de la jarja. Por otro lado, este ajuste no se produce en el enjarje de la bóveda del sotocoro del convento de San Francisco (Alcázar de San Juan) -construido alrededor de 1532, aunque su autoría permanece desconocida-, lo que produce un encuentro defectuoso, ya que el tercelete debe interrumpirse de forma abrupta para dejar hueco al perpiaño.

\section{CONSTRUCCIÓN DE LOS NERVIOS}

\subsection{Arcos de curvatura única: simplificación de dovelas}

De todos es conocido el uso del baibel como herramienta de talla de las dovelas que forman los arcos en las bóvedas de crucería góticas. Siendo una escuadra con un brazo recto y otro que reproduce la curvatura del arco, cada nervio queda por tanto definido con un baivel. Las bóvedas tardogóticas poseen dovelas con una longitud nada desdeñable, por lo que necesariamente son piezas curvas que se tallan siguiendo la curvatura de sus arcos (Figura 5A).

Sin embargo, hemos encontrado grandes diferencias en la construcción de los arcos
Based on the direct study of some late Gothic and modern surbased vaults, it has been confirmed that the criterion requiring that the rib axes cross at one point is not met. In fact, it is quite usual for longer ribs - generally transverse arches- to separate from the rest, so that the axis is off-centre, which avoids inadequate intersections of the tas-de-charges. Two opposite cases are shown in Figure 4. In the vault in the underchoir in the convent of San Telmo (San Sebastián) -built between 1544 and 1562 with designs by Fray Martín de Santiago-, the transverse arch is displaced with regard to the interior ribs, which makes the construction of the tas-de-charge easier. By contrast, this adjustment is not found in the tas-de-charge of the vault in the underchoir in the convent of San Francisco (Alcázar de San Juan) -built in around 1532, although it is still not known who built it-, which produces a defective joint, since the tierceron must be abruptly cut to leave an opening for the transverse arch.

\section{CONSTRUCTION OF THE RIBS}

\subsection{Single centered arches: voussoir simplification}

Everybody acknowledges the bevel as the main tool used to carve the voussoirs that make up the arches in Gothic cross ribbed vaults. The bevel, a framing-square with one straight arm and another that reproduces the arch's desired curvature, defines each rib of the vault. Late gothic vaults have rather long voussoirs, which therefore have to be curved, cut to follow the same curvature of the corresponding arches (Figure 5A).

However, we have found great differences between the construction of the arches of these vaults and older cross ribbed vaults.
4. A. Convento de San Telmo (San Sebastián); B. Convento de San Francisco (Alcázar de San Juan).

4. A. Convent of San Telmo (San Sebastián); B. Convent of San Francisco (Alcázar de San Juan).

5. A. Dibujo de la labra de una dovela con baibel. Bóveda tardogótica de la Iglesia parroquial de Nuestra Señora de las Nieves, Manzanares El Real (Madrid). Dibujo de Roberto Fernández Díaz; B. Dibujo de la labra de una dovela con escuadra. Bóveda gótica del refectorio del Monasterio de Santa María de Huerta (Soria).

5. A. Drawing of work on a voussoir with a bevel. Late Gothic vault in the parish church of Nuestra Señora de las Nieves, Mazanares El Real (Madrid). Drawing by Roberto Fernández Díaz; B. Drawing of work on a voussoir with a framing-square. Gothic vault in the refectory of the Monastery of Santa María de Huerta (Soria).
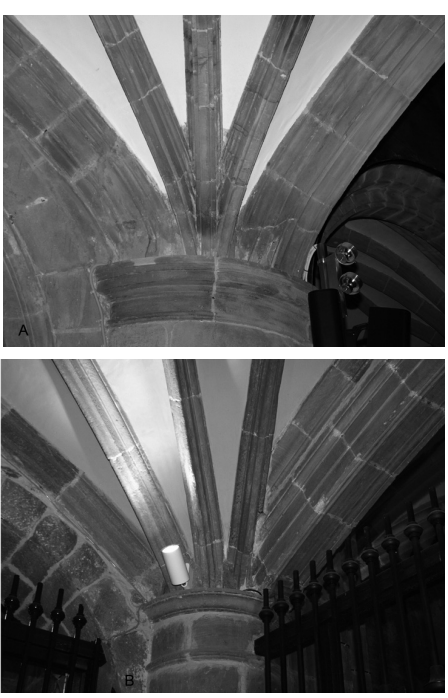

A
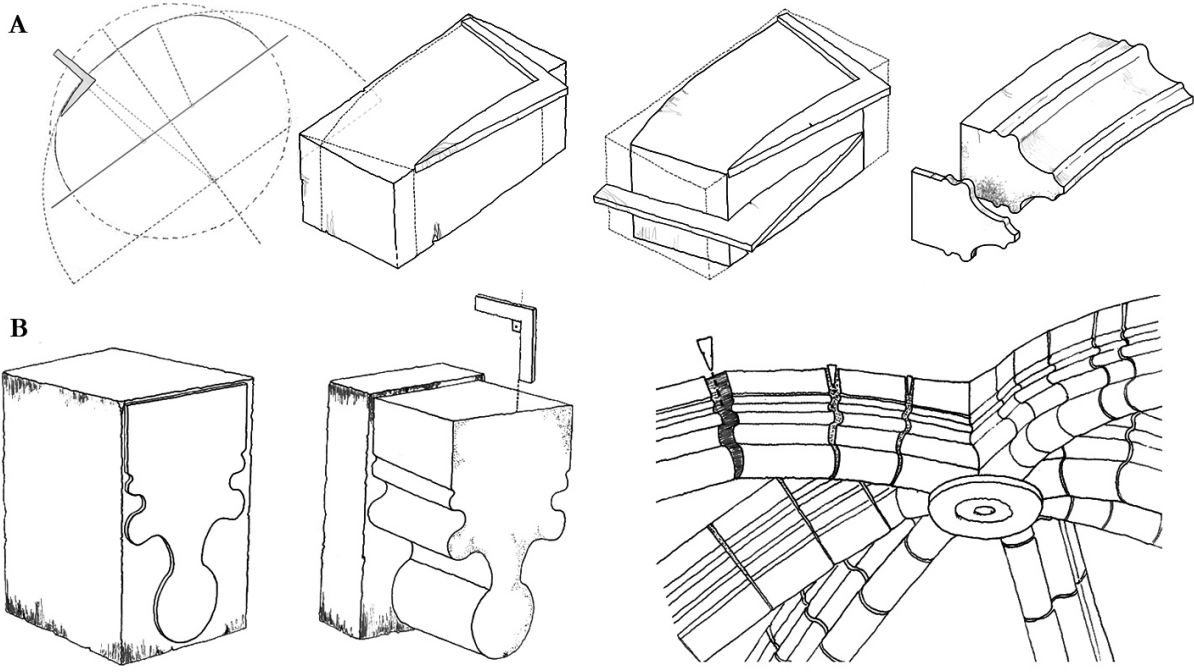
6. A la izquierda, dovelas rectas y variación de grosor de los planos de lecho. En el centro, una clave donde se aprecian sus brazos rectos y las dovelas trapezoidales de transición entre claves y arcos. A la derecha, comprobación in situ de la falta de curvatura en dovelas. Bóvedas sexpartitas del refectorio gótico del Monasterio de Santa María de Huerta (Soria).

6. On the left, straight voussoirs and variation in the thickness of the joints. In the centre, a keystone; where straight arms can easily be distinguished and trapezoidal transition voussoirs between the keystone and the arches. On the right, on site confirmation of the lack of curvature of the voussoirs. Sexpartite vaults in the Gothic refectory in the Monastery of Santa María de Huerta (Soria).

7. Geometría de los arcos carpaneles.

7. Geometry of basket arches. entre dichas bóvedas y los abovedamientos de crucería más antiguos. En las bóvedas sexpartitas de las catedrales de Sigüenza (siglo XIII), Ávila (1172) y Cuenca (siglo XIII), y el refectorio del Monasterio de Santa María de Huerta (1223-1225), hemos podido comprobar que las dovelas carecen por completo de curvatura. Su dimensión longitudinal es considerablemente corta en comparación con otros ejemplos posteriores.

Para ilustrar este sistema nos centramos en las bóvedas sexpartitas del refectorio de Santa María de Huerta (10). Sus dovelas son rectas, sin curvatura, y por tanto iguales para todos los arcos. Para tallar estas piezas no se ha utilizado baibel, sino una escuadra, instrumento medieval de labra formando por dos brazos (11), cuya función es comprobar la ortogonalidad de las dos caras de la dovela, como se muestra en la Figura 5B. Probablemente se colocaban pequeñas cuñas de madera o de piedra en la cara del trasdós de las dovelas, y de esta forma se iba curvando su posición en el espacio ligeramente hasta configurar la totalidad del arco (Figura 6). El arco debe estar dividido en un alto número de dovelas, cuantas más mejor, ya que se adaptará de forma más precisa a la curva del arco. Esta estrategia evitaba errores en obra, al ser todas las dovelas iguales, y permitía, sin tener todos los arcos la misma curvatura, simplificar su ejecución.

\subsection{Arcos de doble curvatura: soluciones prácticas}

Las bóvedas rebajadas emplean usualmente dos tipos de arcos: escarzanos (curvatura única) y carpaneles (curvatura múltiple). Los segundos -que tienen la forma de un semióvalo- poseen una geometría más compleja (Figura 7), lo que dificulta en cierta medida su trazado, pero por el contrario son más flexibles a la hora de adaptarse a trazados muy diversos, ya que dadas la luz y la flecha existen infinitas soluciones posibles.
In the sexpartite vaults of the cathedrals at Sigüenza (13th century), Ávila (1172) and Cuenca (13th century), and in the refectory in the Monastery of Santa María de Huerta (1223-1225), we were able to confirm that the voussoirs have no curvature whatsoever. Their longitudinal dimension is considerably shorter than that of other later examples.

To illustrate this system we shall focus on the sexpartite vaults in the refectory of Santa María de Huerta (10). Its voussoirs are straight, without any curvature, and therefore the same for all the arches. These pieces have not been carved using a bevel but using a framing-square, a medieval cutting instrument made of two arms (11), used to confirm that two sides of a voussoir are orthogonal, as shown in Figure $5 B$. Small wooden or stone wedges were probably placed on the extrados between the voussoirs, slightly curving their layout to gradually configure the complete arch (Figure 6). The arch must be divided into a great number of voussoirs, the more the better, as it will adapt more precisely to the arch's curvature. This strategy avoided mistakes when building the arch, as all voussoirs were the same, and enabled construction work to be simplified, even if the arches did not have the same curvature.

\subsection{Double curvature arches: practical solutions}

Surbased vaults usually employ two types of arches: segmental (one single curvature) and basket arch (multiple curvature). The latter-semi oval in shape- have a more complex geometry (Figure 7), which makes their conceptual layout more difficult, but are on the other hand more flexible in adapting to different spaces: with given span and load, these arches offer endless solutions.

Therefore, to draw a semi-oval, with defined span and load, another variable is required -bottom curvature, top curvature or point of tangency-. The essentially practical approach of this design was the base on which to develop ways to modify and adjust
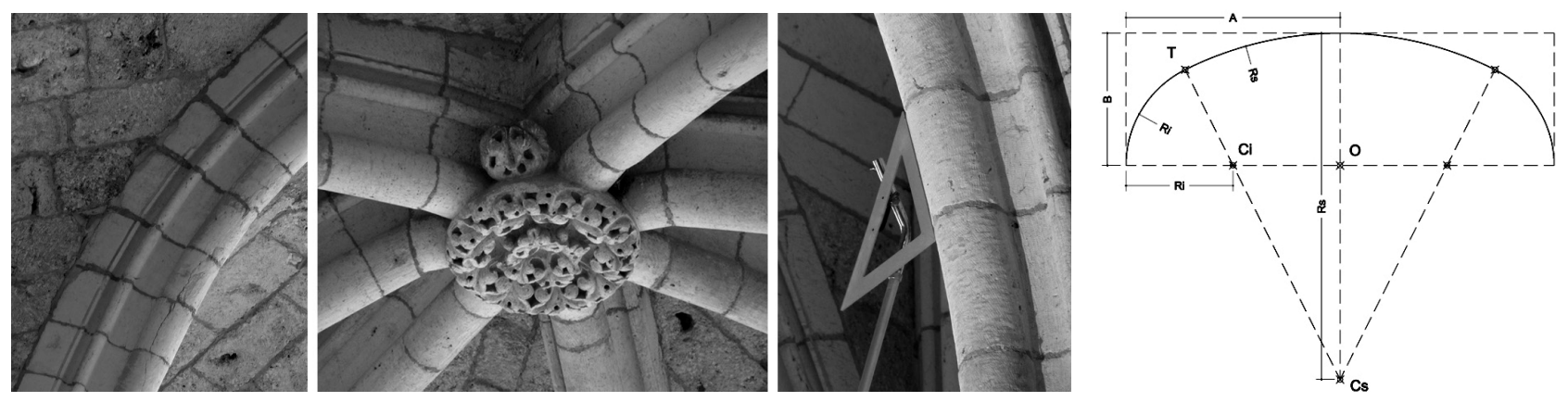
Por ello, el trazado de un semióvalo, en el que la flecha y la luz están predefinidas, precisa de la determinación de una variable más -curvatura inferior, curvatura superior o punto de tangencia-. La concepción esencialmente práctica del diseño fue la base para desarrollar una serie de recursos, que mediante la modificación y ajuste de la integridad geométrica del arco carpanel, optimizaban la construcción.

\section{Discontinuidades en el trazado}

El trazado directo de un óvalo a partir de sus ejes se consigue mediante procesos de una relativa complejidad, y posiblemente eran desconocidos en la época medieval. Por ello, los maestros canteros resolvieron en la mayoría de los casos el trazado a partir de la luz del arco, mediante un proceso de tanteo y ajuste progresivo hasta obtener una solución adecuada que encajase en la flecha predefinida. En este sentido, se han detectado algunos recursos geométricos, que parten de una determinada curvatura inferior (Figura 8).

El primero de los recursos identificado consiste en la rotación de la curva superior alrededor del punto de tangencia, modificándose la posición de la clave (Figura 8B). Este giro rompe sin embargo la continuidad con la curva inferior, produciéndose un pico en el punto de contacto entre ambos, que sin embargo pasa desapercibido a la vista. Por ello, este recurso permite ajustar la posición de la clave de un modo sencillo y práctico, sin que la discontinuidad sea perceptible. Este recurso se ha identificado en las bóvedas del sotocoro del convento de San Marcos de León y del convento de San Esteban (Salamanca). La construcción de la nave de la iglesia se sitúa entre 1529 y 1532, siendo su autor Juan de Álava.

\section{Rotación de curvatura de arranque}

Otra opción para ajustar el arco carpanel a partir del primer tanteo implicaría modificar ambas curvaturas superior e inferior (Figura 8C). Este recurso se basa en la rotación de la curvatura inferior alrededor del punto de arranque, o, lo que es lo mismo, el desplazamiento del centro de curvatura inferior fuera de la línea de impostas. Dicha modificación provoca la inclinación de la pendiente de salida del arco, que ya no permanece vertical. De este modo, a partir de un arco inicialmente tanteado, se podría corregir la situación de la clave mediante la rotación del arco, sin que se formen discontinuidades en su desarrollo.

Este recurso se ha detectado en las bóvedas del sotocoro del convento de Santo To- the geometry of the basket arch, optimising the construction process.

\section{Discontinuities in the conceptual layout}

Drawing an oval directly from its axes requires following a relatively complicated process, possibly unknown in the Middle Ages. Therefore, in most cases master masons solved the problem by drafting the outline from the arch's span, following a trial and error process, gradually adjusting the shape until an adequate solution was found to fit the predefined load. In this way, several geometric techniques have been identified which are based on a specific bottom curvature (Figure 8 ).

The first technique is the rotation of the top curvature around the point of tangency, modifying the position of the keystone (Figure $8 B$ ). However, this rotation breaks continuity with the bottom curve, producing an abrupt angle at the point of contact between the two, which is not, however, visible to the naked eye. Consequently, this technique allows the position of the keystone to be adjusted in a simple and practical way, avoiding perceptible discontinuity. This technique has been identified in the vaults of the underchoir at the convent of San Marcos de León and the convent of San Esteban (Salamanca). The church's main nave was built by Juan de Alava between 1529 and 1532.

\section{Rotation of the curvature at the springer}

Another option to modify the basket arch from the outset would be to modify both the top and bottom curvatures (Figure 8C). This technique is based on the rotation of the bottom curvature around the springer, or, in other words, shifting the centre of the bottom curvature away from the impost line. This modification causes inclination of the initial slope of the arch, which is no longer vertical. Thus, based on a first attempt to design the arch, the position of the keystone could be corrected by rotating the arch, without creating any discontinuities along its length.

This technique has been observed in the vaults of the underchoir at the convent of Santo Tomás (Ávila) -built between 1482 and 1493, attributed to Juan Guas or Martín Solórzano, who succeeded him in the works-; the monastery of San Jerónimo (Granada) -built between 1519 and 1543 following the design by Enrique Egas and possible modifications by Jacobo Florentino and Diego de Siloé-; the monastery of San Telmo (San Sebastián) -built between 1544 and 1562 following the design by 
8. Ajuste de arcos carpaneles. A. Arco carpanel inicial; B. Rotación de la curvatura superior; C. Rotación del arco completo.

8. Adjustment of basket arches. A. Initial basket arch: B. Rotation of top curvature; C. Rotation of full arch.

9. A. Sotocoro del monasterio de Santa María de Oseira (Cea); B. Trazado de su arco ojivo con tres curvaturas.

9. A. Underchoir of the monastery of Santa María de Oseira (Cea); B. Design of its diagonal arch with three curvatures.

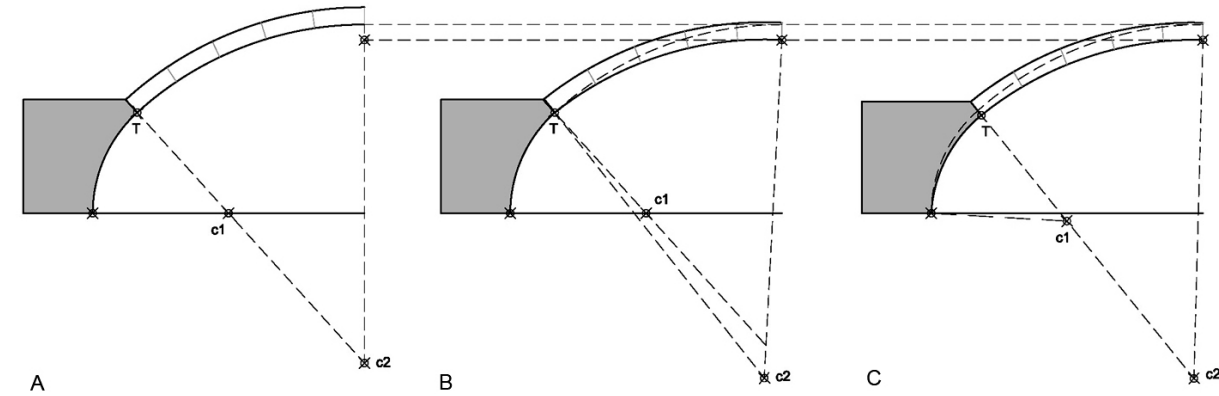
8

más (Ávila) -construido entre 1482 y 1493, con trazas atribuidas a Juan Guas o Martín Solórzano, que le sucedió en las obras-, el monasterio de San Jerónimo (Granada) -construido entre 1519 y 1543 con una traza original de Enrique Egas y posibles modificaciones de Jacobo Florentino y Diego de Siloé-, el monasterio de San Telmo (San Sebastián) -construido entre 1544 y 1562 con trazas de Fray Martín de Santiago-, en el monasterio de Santa María del Parral (Segovia) -construido entre 1486 y 1503 con un diseño de Juan Guas-, así como en el monasterio de San Juan de los Reyes (Toledo) -construido entre 1476 y 1485 también siguiendo las trazas de Juan Guas-. Como se puede observar, este recurso es bastante común, empleándose por maestros de diversas escuelas y ámbitos geográficos, si bien fue el bretón Juan Guas quien lo empleó con mayor profusión.

Curvaturas de ajuste

Finalmente, el último recurso detectado para la modificación de un arco ovalado es el más singular y complejo de todos, y se ha encontrado en la bóveda del sotocoro del monasterio de Santa María de Oseira, (Cea, Orense), construida entre 1545 y 1560, aunque desconocemos su autoría. La forma de la bóveda tiene dos rampantes rectos horizontales, generándose una superficie de extrema planicidad, lo que la convierte en un caso excepcional (Figura 9A).

Para resolver esta volumetría tan singular, los arcos diagonales han de tener una curvatura superior de radio muy elevado. Por otro lado, la curvatura inferior de todos los nervios se repite con el fin de simplificar su talla y ejecución. En estas condiciones, habría sido muy difícil conseguir un adecuado encaje de estas dos curvaturas siguiendo estrictamente las pautas geométricas de un arco ovalado. Por todo ello, la excepcionalidad de este caso radica en la introducción de una pieza trazada con una tercera curvatura, que sirve como transición y adaptación entre los arcos inferior y superior (Figura 9B). Sin embargo, dicha curvatura intermedia no mantiene una tangencia per-
Fray Martín de Santiago-; the monastery of Santa María del Parral (Segovia) -built between 1486 and 1503, designed by Juan Guas-; and at the monastery of San Juan de los Reyes (Toledo) -built between 1476 and 1485, also following the design by Juan Guas-. This technique is quite common, as can be seen, used by masters of several schools and from different geographical areas. It was, however, used more profusely by the Breton Juan Guas.

\section{Adjustment curvature}

Finally, the last technique found to modify an oval arch is the most distinctive and complex of them all, and was found in the vault of the underchoir in the monastery of Santa María de Oseira (Cea, Orense), built between 1545 and 1560, author unknown. The vault has two straight horizontal rampant arches, generating an extremely flat surface, which makes this an exceptional case (Figure 9A).

To address such special volumetrics, the upper curvature of the diagonal arches must have a very large radius. In contrast,
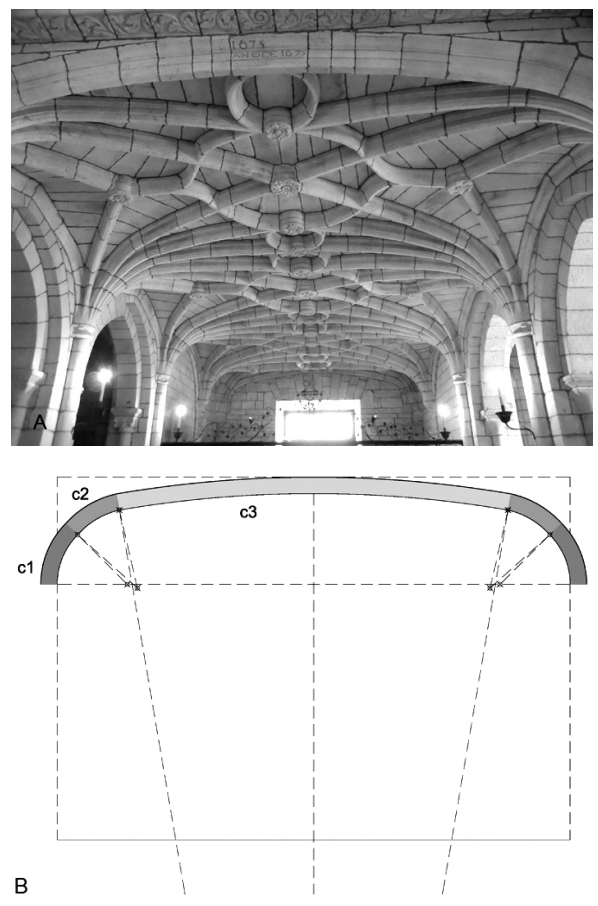

9 
fecta con las otras dos, sino que se obtiene de un modo aproximado para resolver adecuadamente su encuentro. Es decir, se habrían definido a priori sendas curvaturas inferior y superior, de modo que la curvatura intermedia se obtendría mediante tanteo, para que sirviese como ajuste aparente entre las dos, sin que se forzase estrictamente la tangencia entre las tres curvas, obteniéndose un resultado aproximado y adecuado a la percepción del espectador. Como se puede observar, la praxis constructiva se prioriza sobre la rigurosidad de unos trazados geométricos puros, permitiendo la materialización de una idea volumétrica inicial y optimizando al mismo tiempo el proceso constructivo.

\section{CONSTRUCCIÓN DE LAS CLAVES}

También en la talla de las claves podemos ver una serie de soluciones prácticas que, modificando la integridad geométrica, permite obtener ventajas constructivas. Se pueden distinguir dos tipos de claves (12); por un lado, las de molde revirado, con el eje del cilindro en vertical y que se tallan desde su trasdós; y por otro las de molde cuadrado, orientadas hacia el centro de la bóveda (su eje es perpendicular a la superficie de plementería) y que se tallan desde su cara de intradós con ayuda de su plantilla en verdadera magnitud (Figura 10). Las claves tienen normalmente los brazos con la curvatura de los arcos que acometen contra ella. Además los planos de lecho de estos brazos pueden ser verticales o presentar ángulos distintos según la inclinación de los arcos que llegan a ellos.

Sin embargo, encontramos ejemplos que nuevamente no siguen las pautas generalmente utilizadas para tallar estos elementos. En el refectorio de Santa María de Huerta, en la catedral de Sigüenza y en la catedral de Ávila, las claves presentan una talla más sencilla (11). Los brazos son muy cortos, para evitar errores, pero especial- the lower curvature of all the ribs is repeated in order to simplify carving and construction. Under these circumstances, it would have been very difficult to achieve correct assembly of these two curvatures, strictly following the geometrical patterns of an oval arch. For all these reasons, this case is exceptional due to the introduction of a piece with a third curvature, serving as a transition between the lower and upper arches (Figure 9B). However, this intermediate curvature and the other two do not form a perfect tangent but the curve is obtained as an approximation so that they meet adequately. That is, the lower and upper curves will have been defined beforehand, so that the intermediate curvature can be obtained by trial and error and can be used as an apparent adjustment between the two, by forcing tangency between the three curves. An approximate result is therefore obtained which is adequate in the eye of the viewer. As can be seen, constructive praxis is prioritized over the rigor of pure geometrical lines, allowing the initial volumetric idea to materialize and at the same time optimizing the construction process.

\section{CONSTRUCTION OF THE KEYSTONES}

A series of practical solutions can also be seen in the carving of the keystones which, by modifying the geometric integrity, allows several constructive advantages to be obtained. Two types of keystones can be distinguished (12); those made from a twisted mould, where the axis of the cylinder is vertical and carved from their extrados; and those made from a square mould, oriented towards the centre of the vault (their axis thus perpendicular to the surface of the severies) and carved from their intrados with the help of a life size template (Figure 10). The arms of the keystones normally have the same curvature as the arches which connect to them. Also, joints between the pieces of these arms
10. Talla de dos claves tardogóticas, una de molde cuadrado y la otra de molde revirado. Iglesia parroquial de Nuestra Señora de las Nieves. Manzanares el Real (Madrid). (Dibujos de Roberto Fernández Díaz).

10. Carving of two late Gothic keystones, one with a square mould and one with a twisted mould. Parish Church of Nuestra Señora de las Nieves, Manzanares el Real (Madrid). (Drawings by Roberto Fernández Díaz).
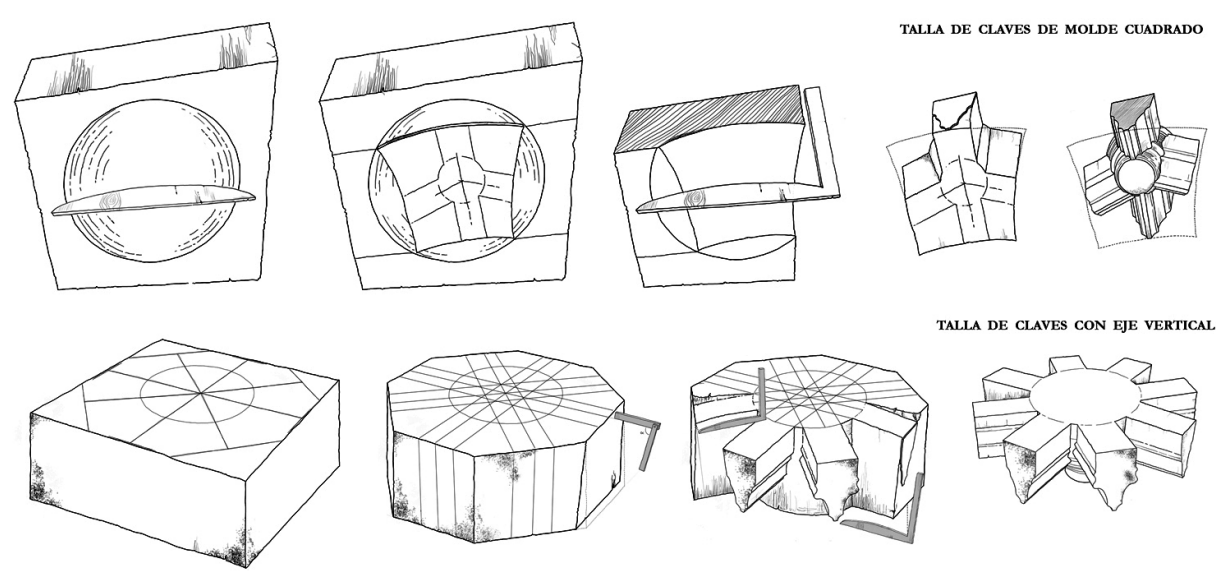

TALLA DE CLAVES CON EJE VERTICAL

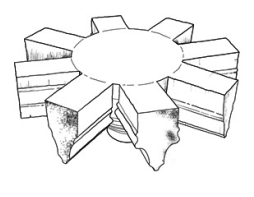


11. Talla de una clave gótica con escuadra de ángulo recto. Refectorio gótico del Monasterio de Santa María de Huerta.

11. Carving of a Gothic keystone with a square-angled framingsquare. Gothic refectory in the Monastery of Santa María de Huerta. mente también porque al ser rectos -no tienen curvatura-, es necesario que su longitud sea la mínima posible.

Las claves se componen de un cilindro central desde el que parten radialmente los brazos que componen los arcos de la bóveda. Éstos son rectos, por lo que forman un ángulo de $90^{\circ}$ con el eje del cilindro central. Este detalle facilita enormemente su talla. La labra de estas claves es idéntica a las de molde revirado ya que ambas tienen su eje vertical. Primero se desbastará un paralelepípedo colocando en su cara superior la planta de la clave. Se cortan sus caras paralelas al eje del cilindro, para lo que se requiere una escuadra con ángulo recto. Se talla la pieza desde su planta y para terminar se coloca la plantilla de testa sobre cada nervio dándoles su forma. La inclinación del trasdós de los brazos de la clave continúa la curvatura del nervio hasta encontrase con el cilindro. De esta forma se garantiza el buen apoyo de la plementería, permitiendo la continuidad de su suave curvatura.

Este proceso requiere de pequeños ajustes in situ (Figura 11). La última dovela de cada arco tiene que ser necesariamente trapezoidal en su encuentro con la clave. De esta forma se resuelve la transición entre la curvatura de los arcos y los brazos rectos de la clave. Este recurso pasa inadvertido en los arcos de mayor recorrido, donde la transición entre los lechos de corte de las dovelas y los brazos de la clave es más suave. En cambio, se percibe claramente en los arcos de menor recorrido, donde se produce un cambio brusco de curvatura entre ambos.

Este tipo de claves con brazos rectos no solo se encuentran en las bóvedas protogóticas. Existen ejemplos en el tardogótico, como en el convento de San Juan de los Reyes (Toledo) -obra de Juan Guas, realizada entre 1476 y $1485-$, donde se ha optado por esta talla más simplificada, probablemente porque los motivos decorativos colgantes
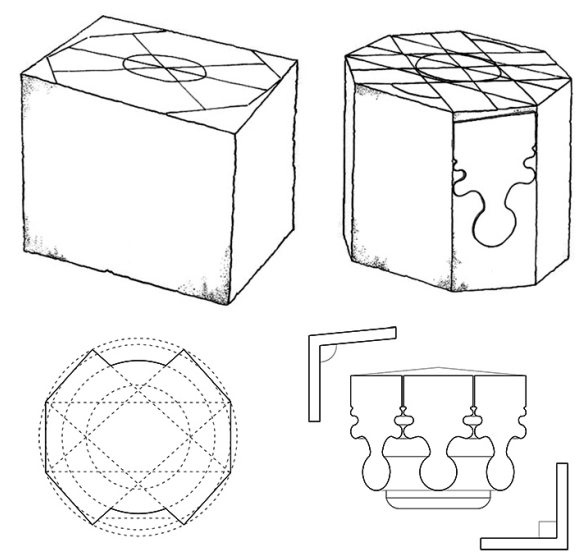

can be vertical or present different angles depending on the inclination of the arches that meet them.

However, we find examples which once again do not follow patterns generally used to carve these elements. In the refectory of Santa María de Huerta, in the cathedral of Sigüenza and in the cathedral of Ávila, the keystones show much simpler carving (Figure 11). The arms are very short, to avoid mistakes, but it is also necessary to make them as short as possible as they are straight, they have no curvature.

Keystones have a central cylinder from which arms radiate, these being the arches of the vault. These arms are straight, thus forming a $90^{\circ}$ angle with the axis of the central cylinder. This facilitates their carving enormously. Carving of these keystones is identical to that of twisted mould keystones, as they both have a vertical axis. First, a parallelepiped is roughed down by placing the keystone plan on its upper face. The two faces parallel to the cylinder axis are cut, with the help of a square-angled framing-square. The piece is then cut from its base and, finally, the template is placed upon each rib, giving it its shape. The slope of the intrados of the arms of the keystone continues the curvature of each rib until it meets the cylinder. This guarantees good support for the severies, giving continuity to its gentle curvature.

This process requires small on-site adjustments (Figure 11). The last voussoir of each arch must necessarily be trapezoidal where it meets the keystone. Thus, transition between the curvature of the arches and the straight arms of the keystone is solved. This technique goes unnoticed in longer arches, where transition between the joints of the voussoirs and the arms of the keystone is gentler. By contrast, this transition is clearly visible in the shorter arches, where an abrupt change of curvature is produced between them.
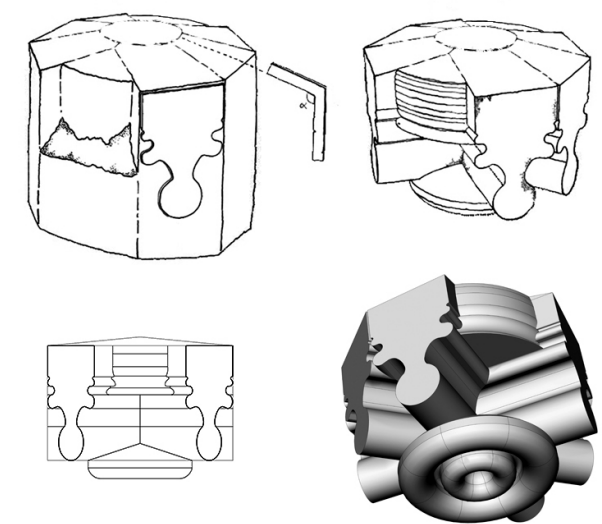
son tan grandes que impiden ver las claves (Figura 12). En este caso, el autor demuestra una especial perspicacia para mostrar una excelente calidad en la talla allí donde las piezas quedan vistas -por ejemplo en el complejo enjarje-, y sin embargo ahorra esfuerzos en las zonas ocultas, optimizando el proceso constructivo.
These keystones with straight arms are not only found in Early Gothic vaults. There are examples in Late Gothic, such as the convent of San Juan de los Reyes (Toledo) the work of Juan Guas, built between 1476 and 1485-, where this more simplified carving was chosen, probably because the hanging decorative motifs are so large that they obstruct the view of the keystones (Figure 12). In this case, the author was particularly shrewd in showing an excellent quality of carving where the pieces can be seen -for example in the complex tas-decharge-, but saves on work in the hidden areas, optimizing the constructive process.

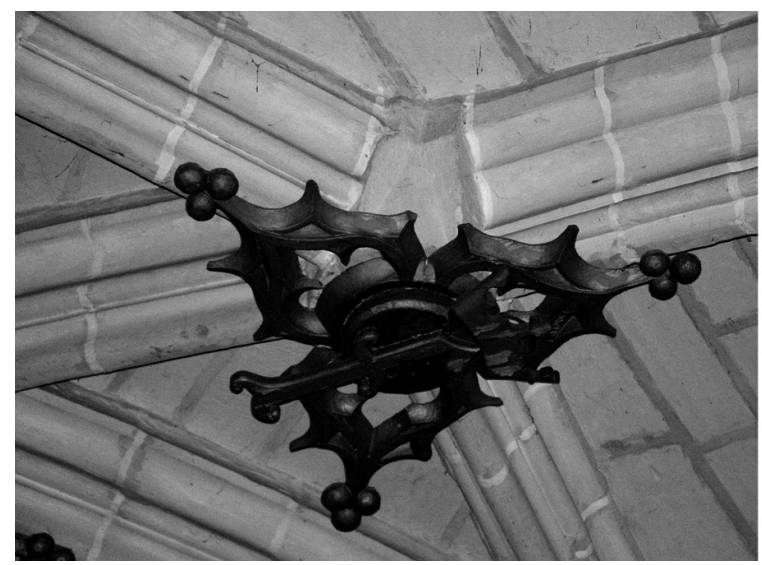

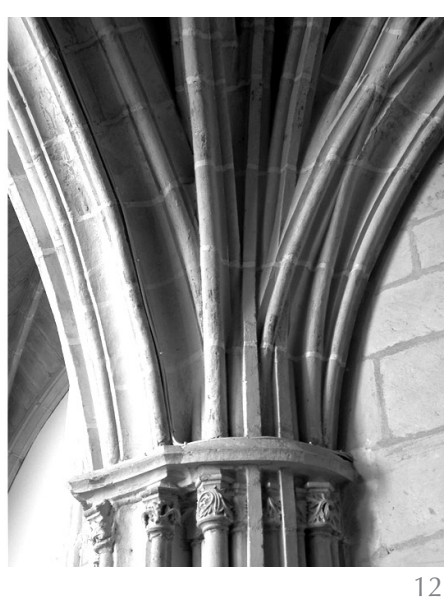

\section{CONCLUSIONS}

As demonstrated by the examples in this article, the constructive system of the cross ribbed vault had the advantage of enormous flexibility and versatility, thanks to which the medieval masters could develop ingenious techniques to optimize the constructive process. From adapting vaults to pre-existing structures -with the complex conditions of the surroundings-, to specific solutions for the tas-de-charges, ribs or keystones, different systems can be found to modify or alter what we could consider to be the "geometric integrity" of the design, in order to obtain constructive advantages. Therefore, it can be deduced that in most cases master masons gave priority to construction practice over purist geometric conception, taking maximum advantage of their hard work and techniques, without the final perception of the finished vault being affected. Thus, from Early Gothic sexpartite vaults to late Gothic in the modern era, in the most varied schools and geographical areas, the presence of this type of technique is constant, becoming therefore one of its most significant invariant characteristics. However, master masons could develop this type of solution thanks to a profound understanding of the constructive technique, on the one hand, and its great flexibility and versatility on the other, and
12. Clave de brazos rectos en la bóveda del sotocoro del convento de San Juan de los Reyes (izquierda) y jarjas de la misma bóveda (derecha).

12. Straight armed keystone in the vault of the underchoir of the convent of San Juan de los Reyes (left) and tas-de-charge in the same vault (right) chando al máximo los esfuerzos y recursos, sin que se resintiese la percepción final de bóveda terminada. Así, desde las prime ras bóvedas góticas sexpartitas hasta las tardogóticas de época moderna, en las más variadas escuelas y ámbitos geográficos, la presencia de este tipo de recursos es una constante, convirtiéndose por lo tanto uno de sus características invariantes más significativas. Sin embargo, los maestros canteros pudieron desarrollar este tipo de soluciones gracias al profundo conocimiento de

\section{2}


la técnica constructiva por un lado, y de su elevada flexibilidad y versatilidad por otro, siendo estas dos características las que permitieron crear los más variados y complejos diseños de redes nervadas con un alto grado de sistematización y brillantez. both these characteristics allowed the most varied and complex designs of highly systematized and brilliant cross ribbed webs to be created.

\section{REFERENCIAS / REFERENCES}

(1) Palacios Gonzalo, J.C. (2009). La cantería medieval, la construcción de la bóveda gótica española. Madrid. Munilla-Lería.

(2) Gómez Martínez, J. (1998). Bóvedas de crucería. El gótico español en la edad moderna. Valladolid. Universidad de Valladolid.

(3) Shelby, Lon R. 1997. The geometrical knowledge of medieval master masons. Studies in the history of civil engineering. Vol. 1: The engineering of medieval cathedrals. Aldershot. Ashgate Publishing Limited.

(4) Lambert, E. [1931] (1985). El arte gótico en España. Madrid. Editorial Cátedra.

(5) Juste Ballesta, J. (2007). Transformación y Restitución de la Catedral de Sigüenza y su entorno urbano. Tesis doctoral en la Universidad Politécnica de Madrid.

(6) Muñoz Párraga, Ma . del C. (1987). La Catedral de Sigüenza (Las fábricas románica y gótica). Guadalajara. Publicaciones del Cabildo de la S.I.C.B. de Sigüenza.

(7) Labrada Chércoles, A. (1940). Informe sobre el estado de las obras. Ministerio de la Gobernación.

(8) Andrés Ordax, S. (1990). La iglesia del monasterio: proceso constructivo y análisis artístico. En Rivera, Javier (coord.), Monasterio de San Benito el Real de Valladolid: IV centenario 1390-1990. Valladolid.

(9) Viollet-le-Duc, E. (1996). La construcción medieval. Madrid. Instituto Juan de Herrera.

(10) Maira Vidal, R. (2011). Bóvedas sexpartitas: Traza, estereotomía y construcción. Monasterio de Santa María de Huerta. Actas del Séptimo Congreso Nacional de Historia de la Construcción (Santiago de Compostela). vol. II. Madrid. Instituto Juan de Herrera.

(11) Calvo López, J. (2001). Entre labra y traza. Instrumentos geométricos para la labra de la piedra de sillería en la Edad Moderna. Actas del Sexto Congreso Nacional de Historia de Profesores de Materiales de Construcción de Escuelas de Arquitectura Técnica. Sevilla.

(12) Rabasa Díaz, E. (2000). Forma y construcción en piedra. De la cantería medieval a la estereotomía del siglo XIX. Madrid. Akal ediciones. 